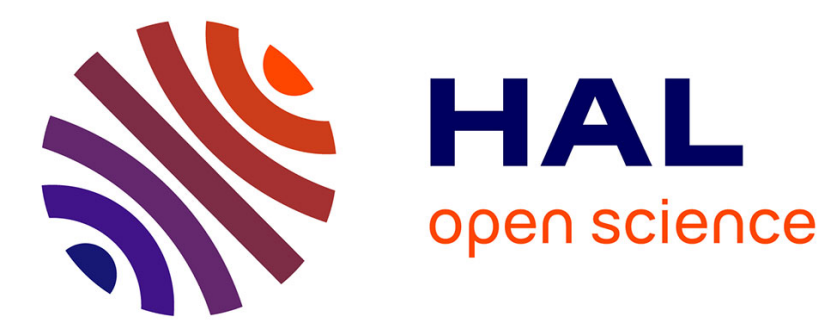

\title{
The dichotomy of Universalism and Particularism in French Guiana
}

\author{
Fred Réno, Bernard Phipps
}

\section{To cite this version:}

Fred Réno, Bernard Phipps. The dichotomy of Universalism and Particularism in French Guiana.

Post colonial Trajectories in the Caribbean : the three Guianas, 2017. hal-02570348

\section{HAL Id: hal-02570348 \\ https://hal.science/hal-02570348}

Submitted on 12 May 2020

HAL is a multi-disciplinary open access archive for the deposit and dissemination of scientific research documents, whether they are published or not. The documents may come from teaching and research institutions in France or abroad, or from public or private research centers.
L'archive ouverte pluridisciplinaire HAL, est destinée au dépôt et à la diffusion de documents scientifiques de niveau recherche, publiés ou non, émanant des établissements d'enseignement et de recherche français ou étrangers, des laboratoires publics ou privés. 
The dichotomy of Universalism and Particularism in French Guiana

Fred Réno and Bernard Phipps

Post-Colonial Trajectories in the Caribbean

The Three Guianas

Edited by Rosemarijn Hoefte, Matthew L. Bishop, Peter Clegg

December 2015 was a landmark in the political history of French Guiana with the election of the new single territorial community - the collectivité unique - which enshrined the official demise of the Région and, more pertinently, the Département that had previously embodied the principle of assimilation of this South American French territory to France. Broadly-speaking, the traditional two-tier system - which exists all over metropolitan France, although, in contrast to those overseas, mainland Regions comprise multiple Departments - has been slimmed down and streamlined into a single political body combining the powers of the former two. Martinique undertook the same reforms, albeit with different sociopolitical overtones, while Guadeloupe, which had turned down the offer of institutional change that was put to the Caribbean Overseas Departments in a 2010 referendum, maintained the departmental institution inherited from the 1946 law that had aligned the former colonies to the metropolitan institutional model. Guadeloupe also kept the Région which was established by François Mitterrand in 1982 and extended to the 'four old colonies' (Guadeloupe, Guyana, Martinique and Réunion). With the former two municipalities of Saint-Martin and Saint Barthelemy which acceded to the slightly different status of Overseas Territories when they split from 'continental' Guadeloupe. France now has five dependencies in the Caribbean region.

While ceasing to be a Département, French Guiana still retains the social and symbolic significance attached to departmentalization. But for reasons related mainly to the history of its settlement, it is, of all these 'assimilated' territories, the one where administration - and more generally, French political culture - have gone through the most distortions. Unlike in Fort de France (Martinique) and Pointe-à-Pitre (Guadeloupe), French colonization was not accompanied by a creolization process 
whereby different groups of people engaged in dynamics of cultural entanglement (Glissant 2009). In this society, the most multicultural of the five French territories of the Caribbean, explicit policies of créolization have fundamentally failed to assimilate the different ethnic groups. As a way of challenging dominant models of integration, the elites of these groups have tended to instrumentalise politics in order to affirm and consolidate their existence. In this strategy game, the Creole group cashed in on a favourable colonial policy to emerge over time as the dominant minority. While its positions are sometimes challenged and downplayed, it still remains today the master of the political game.

In this chapter we wish to highlight two complementary aspects of French Guiana's political history: on the one hand, everyday political reality appears to represent a challenge to French political culture (Schnapper 1994); yet on the other, the very success of the Creole elites is primarily based on the valuation of the republican ideal. The chapter unfolds in two main stages. We begin by setting the scene and discussing the broad political history of French Guiana. Then, we address the specific ways in which Creole elites have come to dominate politics in the society by drawing on very specific formulations of cultural identity. We conclude by reflecting on some of the wider consequences for contentious politics in this quite distinctive territory.

\section{French Guiana: A Litmus Test of French Political Culture}

Compared to Martinique and Guadeloupe, two key features stand out in the colonial history and sociopolitical reality of French Guyana: space occupation and migration. In this huge $84,000 \mathrm{~km}^{2}$ territory, colonization was first an attempt at the subjugation of the indigenous peoples, followed by an erratic emigration policy supposedly implemented to spark off development. The French presence began with a violent encounter between the colonizer and the Native populations: a 'political and cultural shock' (Mam Lam Fouck 2002:13). In the seventeenth century, the territory was occupied by Amerindians whose political organization was based on a chieftaincy system that would survive the colonization period.

Unlike the island Caribbean - and presumably for reasons related more to the configuration of the space than to the Amerindian settlement itself - the French political-administrative model had to deal with that system. In the island colonies, confined space facilitated the political control of the population by the colonial state. Yet within French Guiana's continental territory, borders are porous, so people 
frequently managed to escape, depending on the circumstances, from those who sought to dominate them. The permanence of the Kali'na settlement, for example, demonstrates clearly the resilience and adaptation of this community, factors intimately linked to the geopolitical context in which it operates. (Grenand, Grenand, 1979). When slavery was abolished in 1848 and former slaves simultaneously obtained French citizenship, the Amerindians were excluded from - or, more precisely, forgotten by - the supposedly 'universalist' Republic. In this sense, the republican ideal seemed paradoxically selective. Full political assimilation through the departmentalization of the colony was not established until 1946.

After the Commune, the Department is the second layer of an administrative layercake that aligns French Guiana with the metropolitan model in accordance with the principle of legislative identity. The trend does not concern Guyana alone, it also applies to the French Caribbean islands. It marks to a certain extent the triumph of the republican ideal in its most grotesque dimension: when the administrative sameness applied to these territories is stretched, resulting in the artifice of 'monodepartmental' Régions, the overseas variants being too small to accommodate several Departments as is the case for mainland France and as provided by the 1982 regionalization law. In French Guiana, then, while the political-administrative sphere is highly uniform, the society is equally highly segmented. In 1965, with the implementation of the Kourou Space Centre, French Guianese witnessed the creation of a demographic, economic and cultural enclave - with vast numbers of Métros, scientists and administrators from France and elsewhere in Europe - that tends to accentuate the segmented nature of the territory. It is as if spatial development and planning could put up with a 'specialization' of cultural differences and economic inequalities. The French Guianese reality is, therefore, a rich cultural kaleidoscope that hides the exclusions affecting Amerindian and Maroon communities.

\section{A Distorting Kaléidoscope}

Implicitly, the Kaléidoscope refers to the image of the melting-pot of Creole identity, woven through the unique histories of different communities which, despite different trajectories, have in common the experience of colonization and assimilationist departmentalization. Some communities that were present before colonization survived colonialism. Some were born out of plantation violence. The late arrivers were attracted by the effects of departmentalization and subsequent policy choices by the French state. Diversity is a major feature in the modern history 
of this entire region which has been configured uniquely by bringing together a large number of peoples. This is widely discussed in much social science work on French Guiana (e.g. Collomb 1999, Mam Lam Fouck 2015 ).

Contrary to popular belief, the Amerindians are not a homogeneous group, and consist of different 'nations'. With the Maroons, they are probably the most marginalized populations within the kaleidoscope. Let us say that we are using the word «Amerindians » for convenience sake only, not ignoring that it has aroused debate primarily among those most concerned who take issue with a term that they find it hard to identify with as it disregards the priority of their presence on the continent prior to its "discovery" by Europeans, who "christened" it America, in contempt of the name of the place and of the name of its First peoples, trampled down in Western ethnocidal taxinomy. Things are different where the Maroons are concerned. University of les Antilles Guyane scholar Jean Moomou, a Maroon himself contends that the Maroons did not reject the colonial Bushinengue denomination given them while they rejected the Plantation system, but parodoxically used it as a tool for self identification and identitarian rooting. The term «Bushinenge » Moomou tells us defines the Guyanese Maroons and literally means «Negroes of the forest». It was coined by the English and adopted by the Dutch to differentiate between the Negroes who were on the plantations and those who had run away. The word alternately spells Bushinengue or Bushinenge, the scientific literature hesitating as it were between the two spellings (Moomou 2013).

The whites, for their part, have different social statuses beyond their metropolitan origin. The Creoles are also a diverse group both in terms of their origins as well as socially: Afro-Guianese from the plantation period, Indians whose ancestors arrives as indentured labourers post-slavery, Creoles from the Caribbean, Chinese traders, Hmong farmers, Haitians, Surinamese, Brazilians; all participate in the cultural entanglement that characterizes creolization (Jolivet 2002:107). While this multicultural reality characterizes all three of the Guianas, one may wonder whether multiculturalism in the French Guianese space is not more pronounced than in its similarly multicultural neighbours if we consider Brazilian and Haitian migration after departmentalization, the Hmong in the 1970s, and migration of Maroons which resulted from political instability in Suriname during the late 1980s.

The Amerindians can be said to assume something of a unique place in this debate. Their diversity and geographic dispersion have not prevented them coming together and mobilizing, making them both an example and a target. Their trajectory illustrates their collective capacity to self-identify. French Guiana reportedly has 
seven Amerindian 'nations' - Kali'na, Wayana, Teko Apalai, Wayana, Lokono, and Pahikweneh - which, depending on circumstances, can form a common front and go from the plural to the singular (Tiouka 2012). Such mobilization is sometimes seen as quasi-imperialist by Creole elites. As Christiane Taubira, who was, until early 2016, French Minister of Justice in the Hollande administration, and has long been French Guiana's pre-eminent political figure, suggested two decades ago: 'The Amerindians of French Guiana that call themselves the Kalina people ... increasingly participate in continental gatherings ... [and] seem to feel it legitimate to stay in the pre-Colombian borders, considering that the continent is fundamentally Amerindian' (Taubira 1995:137). This comment implies that the Amerindian project consciously seeks to distance itself from the people brought to the region by the colonial trade: that is the Creoles. This argument is based primarily on the land claims of first peoples and their conception of property. Taubira contends that the Creoles are forgotten by a public policy that focusses on these kinds of particularistic claims (Taubira 1995:138).

\section{The Land as a Shared Bone of Contention}

Amerindians view the land as both the source of their individuality and distinctiveness, as well as their rightful claim for compensation. As one group of Kali'nas put it: 'The management of our lands, which is fundamental for our peoples, has been taken from us, and we demand its return today. It should be facilitated by laws and appropriate measures ensuring fair compensation for the past' (Collomb and Tiouka 2000: 10). This statement by three traditional leaders highlights the endpoint of Amerindian mobilization. In line with other actions developed throughout the Americas, it manifests itself in the French territory of Guiana in the form of a peculiar public policy that challenges the universalist orientation of state authorities. Similarly to the traditional Kali'na leaders defending the Amerindian cause, Creoles call upon the state to implement a land policy on their behalf, in order to repair past injustices.

The debate initiated by some people of African descent on the need for reparations to make up for the wrongs of colonization is reflected in a request for access to land. It is argued that the French overseas territories illustrate a situation of injustice against the son and daughters of slaves. The land was confiscated to their detriment. As Taubira has more recently suggested: 
There are things that could be put in place without expropriation, by explaining very clearly the purpose and significance of public action to buy land. In French Guiana, the State had previously taken over the land, so there it is easier to do this. In the islands of the Caribbean, it is mostly the descendants of the 'masters' who have preserved the land so it remains difficult to implement ... For ten years I have been saying that I believe it is certainly possible. More and more people are aware of this inequality and injustice that perpetuate themselves. The time is ripe to do it intelligently and fairly (Taubira 2013).

So, it seems that all communities render the land a redemption tool whose meaning can vary from one group to another. The construction and the imagination of the Creole group generally correspond to the representations of the French universalist model. But its desire to continue, with the other communities, to counter a "white domination' which is the most important form of suffering, nourishes its distinctive ethnic status.

This is what Marie-Josée Jolivet seems to say, arguing that this dynamic operates to the detriment of class. By privileging community ties, this effectively undermines and minimises forms of class belonging. So Creoles across the social spectrum would tend to reject other communities claiming their 'civilization' and their belonging to the European world. They thus reproduce the process of exclusion that they themselves suffered from during the colonization of the territory (Jolivet 1982:14).

Since they are not listed as a specific ethnic group - and also because they do not view themselves as such - Creoles effectively leave the other groups free to engage in the task of campaigning for and claiming collective rights, and placing them on the agenda of the public authorities. The other groups - and especially the Amerindians - seek via their initiatives and their mobilization to change the form, function and logic of French management of cultural difference in French Guiana.

\section{Ethnic Communes, a Challenge to Republican Universalism}

One can hardly ignore the existence of a legal exception in the French Guianese space where several complementary or competing legal systems coexist, as described by a local judge: 'The six Amerindian tribes and the black maroon population ... live on the basis of systems of norms, mainly customary, that are different from that which applies in the rest of French Guiana. But the state itself adapts its behaviour, often 
silently'. Moreover, taxes are not raised from Amerindians, and certain offenses are not investigated on account of the 'indulgence' of the local gendarmerie (Peyrat 1999:16-17). This judge comes to the conclusion that there is, in French Guiana, something of an exception to the application of certain principles of the Criminal Code of the French Republic. Similarly, the erection of communes said to be 'ethnic' in nature, is a violation per se of the universalist tenet at the core of French Republican principles. One of the justifications - and, indeed, probably the strongest - of this ethnic division of the public space is cultural.

The municipality of Awala-Yalimapo, founded in 1988, is located in the western part of French Guiana at the mouth of the Maroni and Mana rivers. Its creation was primarily the will of the Amerindian peoples who sought to protect and defend their territory. The example in this commune illustrates the ability of the Amerindians to integrate their cultural specificity in the French universalist public space. It also shows the flexibility of the republican ideal, deemed to be Jacobin. The community's territory coincides with the territory of the municipality. City and tribal councils jointly draw their legitimacy from the election of the people of Awala and Yalimapo. In the commune, public authority and customary authority overlap. They jointly manage the land in a commune-community joint commission established by the municipal council.

This form of governance, mixing French law with customary law, is not exceptional. What is new, though, is the instrument that allows it and the conception of citizenship that results from it. The commune, which is the bottom level of French Republican administration, is based on nonparticularistic values. In the French model of administration, commune and community cannot, a priori, be confused. At Awala-Yalimapo, a cultural council serves as a link between the two. It is composed of councillors appointed by the deliberative assembly, and members of the community appointed by the chiefs, representing the community, the mayor and with traditional chiefs being ex-officio members. The concepts of governance and local democracy serve as an intellectual framework for a project that appears at the same time extensible to other communities as the intercultural dimension of events could be taken to suggest.

This relativizes the critical discourse of the community's spokespersons who tend to denounce the exclusion of the Amerindians. Their existence is recognized and formalized in the public space through the creation of this ethnic commune and the involvement of the mayor in the direction of the Guianese major local authority. In 
fact, the mayor of Awala-Yalimapo John Paul Ferreira held the position of fourth Vice-President in the Regional Council of French Guiana between 2010 and 2015.

However, it would be wrong to infer that the French republican ideal and the universal vocation that goes with it, are definitely befriending multiculturalism. It seems that the dominant trend remains the exclusion of particularism from the public space where universalism is the sole discourse. This arguably accounts not just for the Creoles' overrepresentation in local institutions but for the effective presence of their most illustrious representatives at the summit of the French state.

\section{The Creole Elites at the Service of the Republican Ideal}

To understand the importance of the Creole group in Guiana, one needs to view it through a historical lens. Specifically, we need to trace it back from the colonial era that saw its birth to the political assimilation policy that ensured its socioethnic domination.

\section{The Creole Ethics and the Spirit of Republicanism}

The conditions to demand social equality with mainland France seem to be met in the 1820s, when the demographic and political weight of the free people of colour required that the slave colonial society structures be changed (Mam Lam Fouck 2006 a:9). But it was in 1848, with the abolition of slavery and the advent of a universal citizenship that the Creole domination began. However, equal citizenship was not to be taken at face value. In fact in the Guianese context, besides the metropolitans most of whom were officials, equality concerned first the Creoles.

While the entire population is concerned by the political project of assimilation, the colonial administration separates people according to legal, racial and cultural criteria (Mam Lam Fouck 2006 a:10). In French Guiana, since the late nineteenth century, it seems that, contrary to an established French tradition, ethnic censuses are conducted. The Creoles are distinguished from the 'indigenous tribes' which consist of the Amerindian peoples and the Maroons. In 1946, the year when the departmentalization law was passed, these tribes represented 1,355 people who did not have the status of French citizens. The extension of French citizenship primarily to those who had been freed from slavery resulted in the latter making the republican ideal the framework for their integration into the French nation. It also 
coincided with a Creole ethics whereby cultural particularities do not vanish but entangle and transcend into a rhyzomic whole (Glissant 2009) irreducible to its components (Bibeau 2000).

In French Guiana, republican universalism is of one with the Creole project. In the South American context, Creole particularism is regarded as universalism, which explains both the social and political 'success story' of the Creoles, and the relative marginalization of other ethnic groups. The observation holds true at all levels of responsibility. From the local to the national the Creoles have the upper hand on positions of management and distribution of public resources. Represented in the central government and at the French parliament they also control the management of local affairs. They regard their trajectory as the normal way of building guyanité and accessing the state. From Félix Eboué to Christiane Taubira through Gaston Monnerville, the history of this French territory is a remarkable illustration of the effective fusion of the French republican ideal with the Creole ethics. The three personalities mentioned above are three outstanding creole figures in the French political system. While the Caribbean islands - and Martinique in particular - are known for outstanding 'rejectionist' figures like Aimé Césaire and Frantz Fanon, French Guiana is, somewhat ironically, probably the French overseas territory with the greatest public servants.

\section{French Guiana: A Great Public Servant}

Christiane Taubira surely stands out as the emblematic figure of the contemporary fusion between the republican ideal and Creole ethics. A member of a separatist party, Walwari, she was a member of the French parliament from 1993 to 2012. As the writer of a law that makes the slave trade and slavery crimes against humanity, she has an audience that reaches far beyond France's borders.

As a presidential candidate in 2002, she has built an image and style that make her the muse of a part of the French left. Brilliant and faithful to her humanist convictions, she incurred the wrath of the right and above all the racism of the extreme right which does not hesitate to refer to her origins and to call her - in a derogatory fashion - a monkey. As Minister of Justice from 16 May 2012 to 27 January 2016, and an important figure of the French government in general, she managed to impose her mark through her intellectual and oratorical skills. In her capacity of minister of justice she defended the mariage pour tous (marriage for all) bill, which now allows gay couples to legalize their union. 
Before Taubira, other French Guianese personalities have embodied the Republican ideal occupying important positions in the French political system. In that respect Gaston Monnerville and Félix Eboué are unmatched anywhere else in the overseas territories. Monnerville was a Member of the French Parliament representing French Guiana from 1932 to 1946 . He also served as Under Secretary of State for the Colonies from 1937 to 1938. He then became senator for French Guiana in 1947 and for the metropolitan department of Lot in 1948. He won his fame by accessing the prestigious and highly symbolic function of Chairman of the Republic Council and of the Senate from 1947 to 1968. In his capacity of 'Speaker' of the lower house of parliament he could have acted as head of state as provided by the Constitution. During World War II he defended republican France by a firm commitment against the German occupiers and Marshal Petain's regime. He joined the underground, became captain and commander of the French Forces of the Interior.

His pseudonym of résistant consequently symbolizes the strong sense of his commitment. He called himself Saint Just, after the uncompromising and freedomloving French revolutionary. His allegiance to the republican ideal is unequivocal:

I was trained in civility, love of the Republic and France, on the benches of public school ... That is where I learned to gradually discover a country and a nation which became for my classmates and myself - as they were already for our seniors - the symbol of a high spiritual and human ideal: France, its past, its merits, its mission (Monnerville 1975:19).

Opposed to General de Gaulle in the referendum that was to lead to a change in the constitution, he showed once again his commitment to this ideal by a courageous criticism of De Gaulle he accused of treason when he says: 'There is no more Republic when those who hold the power impose themselves the respect of the law no more' (Alexandre 2001:45). This love of the Republic is rooted in his origins: 'The son from the overseas that I am owes everything to the Republic. It came to my native French Guiana to bring me dignity and culture. It taught me everything and made me what I am' (cited in Alexandre 2001:26).

According to one of his closest collaborators, Monnerville's vitality has to do as much with his ethnic origin and his Négritude as to his French homeland (Alexandre 2001:42). If the man is praised for his merit, his trajectory reveals what French 
republican universalism means. First a personal journey built by free secular education that gives everyone a fair shot at self-fulfilment, then an allegiance to the Republic, which supposedly helps steer clear of communitarian temptation.

Monnerville and Taubira can be said to share a common vision of the republican ideal. The former opposed De Gaulle in the name of the republic, the latter resigned from the government in early 2016 in the name of the rule of law and compliance with republican values. Just as her elder did yesterday, Taubira opposed today a revision of the constitution. The bone of contention was a bill supported by the Head of State - President Hollande - regarding the state of emergency and deprivation of French citizenship for French binational criminals convicted of acts of terrorism. The resignée contends that the Republic has the legal and military weapons to deal with this challenge. True to Aimé Césaire and republican identity, she makes her case and 'throws the book at it' in a book released just days after her resignation (Taubira 2016).

Félix Eboué was born 26 December 1884, of parents descendants of freed slaves. Like others from the overseas territories, the schooling of the young Eboué continued in mainland France where he moved in 1898 with a scholarship. He then began an African journey in the service of the colonial Republic in Paris. As a colonial administrator student he was made available to the Governor of French Equatorial Africa in 1908. For twenty years he represented the interests of France in the region. He notably administered the French colony of Oubangui-Chari between 1903 and 1958, before the territory became independent in 1960 under the name of the Central African Republic. Secretary General of Martinique in 1932, then governor of Guadeloupe in 1936, he urged all the actors involved in social conflicts to "play the game' - that is to look beyond their private interests for the public good (Maurice 1954:23).

But it is his appointment as governor of Chad in 1938 that revealed his loyalty to the republican ideal. A major player in rallying African troops to the allied forces during World War II, his merit is contained in the following response from General de Gaulle to Eboué's initiatives:

I hear the decision made by you and by the territory and troops of Chad to continue the war with honor in the service of France. It is a crucial 
development that will have great repercussion. My joy and pride are extreme as a French man and as a chief (cited in Maurice 1954:33).

Certainly, Eboue is not the only native of the Antilles and French Guiana to have served France in the colonies, but he is arguably the one that best embodied 'the French ideal' during the colonial period. While they doggedly defend a shared representation of the Republic, these figures have never divested themselves of their geographical and cultural origins. All three are from the Creole group that has a real monopoly over local affairs in French Guiana. It is to this that we now return.

\section{Creole Monopoly on Local Politics}

State policies of exclusion of Amerindians and Maroons contributed to the monopolization of local affairs by the Creoles. The emergence of an elite whose aspirations are sometimes divergent did not prevent the domination of those who managed to match Republican universalism and Creole ethics. Amerindians and Maroons live isolated in the forest, away from formal economic activities and administrative control. For a long time absent from the civil register, they had no legal existence and did not benefit from citizenship. They did not become French nationals until 1964 with Guyon 2013).

Twenty years later, Amerindians were to make a solemn entry on the political scene with a speech delivered by Felix Tiouka, one of their spokespersons in the presence of the representative of the French government (Ayangma 2008). To mark the first gathering of the Association of the Indians of French Guiana their president harshly criticized the state, causing the Prefect to leave the event: 'We want recognition of our aboriginal rights, that is to say, the recognition of our territorial rights, our right to remain Indians, and develop our own institutions and culture' (Tiouka 1985). The state remains the main target of the claims as it owns most of the land. It responds with exceptional but highly symbolic compliance-related measures encouraging mostly the universalistic option.

While the ethnocultural minorities' nationalization policy is not exactly a resounding success one cannot deny that things have changed. Individuals from these minorities have exceptional professional and political careers. Academics, business leaders, elected officials, examples are still few and far between but they reflect a new reality. 
In the political field, Brigitte Wyngaarde, a woman and traditional chief, headed the Green Party in the regional elections of 2010. In the town of Camopi, Laurent Yawalou lost the elections for mayor by only two votes.

Other Amerindians manage to get elected and enjoy a representative scope that reaches beyond the boundaries of their community, like Cornelia Sellali Bois Blanc, the first Amerindian woman mayor of a town in French Guiana who was elected in March 2014. John Paul Ferreira, an Amerindian local mayor and a member of the Guianese Socialist Party is the non-Creole elected representative that best symbolizes the will of this community to integrate into a guyanité respectful of differences. Fourth vice president of the regional council he chaired Guyane Technopole, the organization in charge of an innovative economic development. Féreira is not an isolated case. The Maroons mayors of Maripasoula and Papaïchton and vicepresidents of west French Guiana communauté de communes are other exceptions to the Creole rule.

Creole domination sees through the socioethnic make-up of the brand new local authority formed as a result of the elections of 6 and 13 December 2015. Just as was the case with the former two major local authorities (Conseil Général and Conseil Regional) the new institution created to replace them (the Communauté Territoriale de Guyane) is mostly composed of and led by Creoles. Diverse in origin, with frequently misleading surnames, they monopolize the agenda and direction of all representative institutions. The case of the General Council's last president illustrates how porous and irreducible to its components creolization is. A Creole who comes from the Cayenne Chinese quarter, Alain Tien Long, does not hide his Asian ancestry but he does not make it a political issue either.

Out of the 40 Presidents of the General Council French Guiana has had between 1879 and 2015, none has displayed belonging to either the Amerindian community or the Maroon one. Originating mostly from the coast and from Cayenne, they rarely come from the interior territories in which the non-Creole populations are concentrated. The new Assemblée Territoriale consists of 51 members elected for six years. The electoral boundaries have been readjusted into eight voting districts (called sections) supposedly promoting the representation of the various components of the population. The constituency of Basse Mana composed of the Amerindian town of Awala-Yalimapo and the Creole town of Mana is entitled to three delegates in proportion to the size of its population. The current configuration reveals a decline of 
Amerindian presence in decision-making bodies. While the fourth vice president of the former Regional Council was Kali'na, no elected member of the new institution is Amerindian. However, to the satisfaction of the Amerindian representatives, the new political-administrative organization now includes an advisory board for the Amerindian and Maroons populations. Reporting to the Prefect of French Guiana, its implementation confirms the recognition of communities by the state at the highest level of local government. The board can be seized by the highest authorities but may also self-refer any matter within the jurisdiction of the institution that would affect Amerindians and Maroons lives, environment, and cultural activities.

\section{Conclusion}

Since 2003, Amerindian communities in French Guiana has been hit by a wave of teen suicides that presents a difficult challenge to all stakeholders, and primarily the State which sent a mission to investigate the causes of the phenomenon and generate solutions. Suicide rates are eight to ten times higher than those encountered in the rest of French Guyana and France. Besides its dramatic nature, the problem reflects the difficulties for political management of ethnicity in Guiana, and it has badly affected the three major Amerindian groups settled on the top of the major rivers in southern French Guiana. Some young Amerindians arguably find it impossible to cope with the suffering resulting from the brutal clash between two worlds: loyalty to the traditions of the village and to their parents on the one hand, and a plunge into the modern world of school and the city on the other.

Faced with this tragedy, the State's responses are diverse. One of them is the appointment of a sub-Prefect for the communes of the interior who is in charge (among other tasks) of the social integration of Amerindians. Another measure is the establishment in June 2008 of the Advisory Board of Amerindian and Bushinengue populations, intended to play an important advisory role in the new local authority (Décret 2008). Yet this initiative has not been marked by success. Until December 2015, the body had rarely met. With the exception of the prefect and rare selfreferrals, 'no one asks its opinion' (Archimbaud and Chapdelaine 2015:69). Neither the former president of the General Council, nor the former President of the Regional Council held any meetings with it. If a serious issue such as the suicide of Amerindian youth has not triggered a referral, one may rightly wonder what more serious reasons might cause a referral by the president of the new territorial authority? Originally presented as an institutional innovation regarding the political 
accommodation of ethnic claims, the Board could well prove completely ineffective. Indeed, it brings together peoples whose realities seem to call for differential treatment. Certainly the Amerindian and Maroon peoples are both geographically isolated and landlocked as well as marginalized in terms of health and education. They also both aspire to have their traditions better integrated into the public space. But unlike the Amerindians, the Maroons are concentrated on a single river, the Maroni. They constitute an overwhelming majority in four municipalities (Maripasoula Papaïchton, Gan Santi, and Apatou) and will also do so soon in Saint Laurent du Maroni. Their remarkable demographic dynamism could make them a real force in the west of French Guiana (Archimbaud and Chapdelaine 2015: 69).

Calls have already been made within the Amerindian community for other political and ethnic adjustments in response to youth suicide. Brigitte Wyngaarde for example proposed the creation of a new municipality in the locality of Talhuen (Wyngaarde 2011). For now, Paris is turning a deaf ear to the claim as if the universalistic Republican State did not wish to encourage ethnic answers to integration problems. Indeed, in French Guiana as in other places, ethnicization brings about and nurtures community differentiation because of the meaning the elite ascribes to it and the uses resulting from such meaning in their social relations (Bertheleu 2007). Amerindians seek to turn their marginalization into an advantage in their negotiation with the state and the other groups. From the former they expect the public resources they need to share with the latter. The state's will to combine Amerindians and Maroons in the same structures therefore seems incongruous.

That the Amerindians' claim should be so vocal speaks volume about the lack of both horizontal and vertical integration (Birnbaum 1983:423). Divided geographically, less numerous, poorly represented in the institutions, they tend to express more than other communities an identity distress. The comparative discretion of the Maroons could refer to a greater horizontal integration of the group geographically concentrated in the west, and a greater vertical integration whose institutional form is the control of several municipalities. Lagging in both levels of integration the Amerindians fall back on an externalised protest discourse in international forums from which they manage to tilt the French state's policy internally.

The undifferentiated response from the government through the advisory board is a blatant indicator of the difficulties state universalism grapples with. French Guiana may be regarded as a laboratory where two political models compete: the republican 
universalistic model defended by the Creoles, and the communitarian-inspired model represented by the Amerindians and the Maroons to a lesser extent. The Creoles originally raided the political resource, with the Amerindians left stranded on the land they had been disposed of. The latter today demand from the state and partially obtain access to the political resource. Their move does not take the form of 'shareholding interests' in the assimilationist game as it unfolds through traditional French institutions; it is done rather on the Amerindians' own terms on the side lines of these institutions. The constitution of ethnic communes aims at reclaiming land which was hitherto public property and which (re)becomes collectively owned by the Amerindian communities, in accordance with the latter's ancestral values trampled down by European colonization. The recent change in the country's status is not exactly likely to win the Amerindians over to the universalist views as their absence from the new body's composition may well be read as evidence that their long-standing suspicion towards any form of local autonomy as being a reinforcement of the Creole group overwhelming hegemony is grounded. Autonomy, as a way of domiciling power which in this case is in the hands of the Creoles, would only further strengthen the power of the latter. Which leads to the paradox that the Amerindians appeal to the French republican universalist state to defend the Amerindian particularism against the Creole universalist threat that they perceive as an ethnic hegemony.

As for the Creoles, because land is state property as the law stands, they regard it as part of a Republican back country bound to be dealt with in a universalistic way. While the republican model is challenged by the communautarian one, the Creoles, who go for the former, seem nevertheless to react via the latter with a claim for the sharing of the land resource which, even though it might aim at individuals being entitled to a plot of land, is made in the name of an equal treatment for the group the aforementioned individuals belong to. So, it is as if the Amerindians had managed to bring the Creoles on a field that they pretended was not theirs.

\section{References}

Archimbauld, A. and M.-A. Chapdelaine, 2015. Suicides des jeunes Amérindiens en Guyane française : 37 propositions pour enrayer ces drames et créer les conditions d'un mieux-être. Rapport au minister 
[http://www.ladocumentationfrancaise.fr/rapports-publics/154000882-suicides-desjeunes-amerindiens-en-guyane-francaise-37-propositions-pour-enrayer-ces] Alexandre, R. , Gaston Monnerville, un homme d'Etat de la République française, Ibis Rouge Ed. 2001

Ayangma, S. 2008. Représentation politique et évolution territoriale des communautés amérindiennes de Guyane, L'espace Politique 6/3 pp. 2-12

Bertheleu, H. 2007. Sens et usages de l'ethnicization, Revue européenne des migrations internationales vol $23 \mathrm{n}^{\circ} 2$ pp. 2-17

Bibeau, G. 2000. 'Vers une éthique créole' Anthropologie et Sociétés, 24(2): 129-48.

Birnbaum, P. 1983. 'Mobilizations, structures sociales et types d'Etat' Revue française de sociologie 24(3):421-39.

Collomb, G. 1999. 'Entre ethnicité et national: A propos de la Guyane' Socioanthropologie [http://socio-anthropologie.revues.org/113].

Collomb, G. and T. Tiouka, 2000. Na'na Kali'na: une histoire des Kali'na en Guyane. Cayenne: Ibis Rouge.

Glissant, E. 2009. Philosophie de la Relation. Poésie en étendue. Paris: Gallimard.

Grenand, F. et Grenand, P. 1979. Les amérindiens de Guyane française aujourd'hui: éléments de compréhension Journal de la Société des Américanistes Volume 66 Numéro 1 pp. 361-382

Guyon, S. 2011. Politisation et hiérarchies coloniales: Amérindiens et Noirs-marrons à Saint-Paul (Guyane française, 1946-2000), Critique Internationale, 1/n`50 pp. 21-37

Guyon, S. 2013. Des "primitifs" aux "autochtones" savoirs ethnologiques et politiques publiques en Guyane de 1946 à nos jours, in Genèses 2 n 91 pp. 49-70

Jolivet, M.-J. 1982. La question créole, essai de sociologie sur la Guyane française. Paris: ORSTOM.

Jolivet, M.-J. 2002. 'Images de Guyane, entre réduction et cloisonnement' Autrepart 4: 107-24. [www.cairn.info/revue-autrepart-2002-4-page-107.htm] 
Mam Lam Fouck, S. 2002. Histoire générale de la Guyane: des débuts de la colonization à la fin du XXème siècle: Les grands problèmes guyanais. Cayenne: Ibis Rouge

Mam Lam Fouck, S. 2006a. Histoire de l'assimilation: Des vieilles colonies françaises aux départements d'outre-mer: La culture politique de l'assimilation en Guyane et aux Antilles françaises ( $\mathrm{xix}^{\mathrm{e}}$ et $\mathrm{xx}^{\mathrm{e}}$ siècle). Cayenne: Ibis Rouge.

Mam Lam Fouck, S. 2006b. L'histoire de la Guyane depuis les civilizations amérindiennes, Cayenne: Ibis Rouge.

Mam Lam Fouck, S. 2015. La société guyanaise à l'épreuve des migrations 1965-2015, Ibis Rouge

Maurice, A. 1954. Félix Eboué, sa vie et son œuvre, Brussels: Institut Royal Colonial Belge.

Monnerville, G. 1975. Témoignage: De la France équinoxiale au Palais de Luxembourg, Paris: Plon

Moomou, J. 2013. Les Marrons boni de Guyane, luttes et survie en logique coloniale (17121880) Ibis Rouge

Peyrat, D. 1999. Le juge et le lieu: Essai sur le besoin de droit en Guyane. Cayenne: Ibis Rouge.

Schnapper, D. 1994. La communauté des citoyens, Sur l'idée moderne de nation, Gallimard

Taubira, C. 1995. 'Mon peuple Quonvwé' in F. Reno (ed.), Identité et Politique, de la Caraïbe et de l'Europe multiculturelles. Paris: Economica pp. 121-41.

Taubira, C. 2013. 'Rendre leur terre aux descendants d'esclaves' Interview Journal Du Dimanche 12 mai.

Taubira, C. 2016. Murmures à la jeunesse. Paris Philippe Rey.

Tiouka, F. 1985. 'Adresse au gouvernement et au peuple français', Ethnies 1-2:7-10

Tiouka, A. 2012. Mémento à l'intention de François Hollande: Sur la situation et les droits des peuples autochtones de Guyane 
[http://www.blada.com/data/File/2012pdf/tioukahollande1601.pdf]

Wyngaarde, B. 2011. 'Préparer la rencontre (lettre ouverte)', France-Guyane (23 March). [http://gitpa.org/Peuple\%20GITPA\%20500/gitpa500-2BWSuicides\%20.pdf]

Décret $\mathrm{n}^{\circ}$ 2008-562 du 17 juin 2008 relatif à la composition, à l'organization et au fonctionnement $\mathrm{du}$ conseil consultatif des populations amérindiennes et bushinenge de Guyane 